\title{
Thermal behaviour of Miscanthus grasses, an alternative biological fuel
}

Salvatore Collura • Bruno Azambre • Jean-Victor Weber

Published online: 14 September 2006

(C) Springer-Verlag 2006

\section{Environ Chem Lett (2005) 3: 95-99}

Due to a processing error, the title was incorrect in the HTML version of this article. The corrected title is given above.

The online version of the original article can be found at http:// dx.doi.org/10.1007/s10311-005-0007-0

S. Collura $\cdot$ B. Azambre $(\bowtie) \cdot$ J.-V. Weber

Laboratoire de Chimie et Applications (EA 3471), Université de Metz- Rue Victor Demange,

57500 Saint-Avold, France

e-mail: bazambre@iut.univ-metz.fr

Tel.: +33-3-87939106

Fax: $+33-3-87939101$ 